\title{
Phytoplankton-bacteria relationship in the Antarctic marine ecosystem
}

\author{
GILLES BILLEN and SYLVIE BECQUEVORT
}

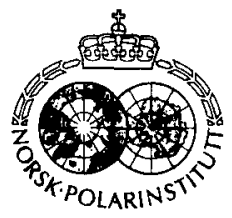

\begin{abstract}
Billen, G. \& Becquevort, S. 1991: Phytoplankton-bacteria relationship in the Antarctic marine ecosystem. Pp. 245-253 in Sakshaug, E., Hopkins, C. C. E. \& Øritsland, N. A. (eds.): Proceedings of the Pro Mare Symposium on Polar Marine Ecology, Trondheim, 12-16 May 1990. Polar Research I0(1).

Time series data of phytoplanktonic and bacterial biomass during the ice retreat period at different latitudes in the Weddell Sea and Prydz Bay areas show a distinct delay in the development of bacteria with respect to phytoplankton. Use of a general ecophysiological model of bacterial growth, along with direct in situ measurements of growth and mortality rates, allowed the simulation of the observed timing of hacterial development. It is suggested that the uncoupling between phytoplanktonic and bacterial development at the earliest stage of the spring ice-edge related algal bloom is not the result of the low temperatures occurring in the Southern Ocean but rather is due to the macromolecular nature of the dissolved organic matter released from phytoplankton.
\end{abstract}

Gilles Billen and Sylvie Becquevort, Groupe de Microbiologie des Millieux Aquatiques, University of Brussels, CP 221. Campus de la Plaine, B-1050 Brussels, Belgium.

\section{Introduction}

That planktonic bacteria directly depend on phytoplankton in aquatic systems devoid of allochtonous input of organic matter is now widely recognized. Evidence for this statement is provided by the correlation which exists between bacterial biomass and chlorophyll $a$ concentration (Linley et al. 1983; Bird \& Kalff 1984) or between bacterial production and both chlorophyll $a$ concentration and planktonic primary production (Cole et al. 1988), over a large range of temperate and tropical aquatic environments. However, the exact nature of the trophic relationship between phytoplankton and bacteria is still a matter of controversy. Exudation by algae of low molecular weight photosynthates has long been considered as the dominant dissolved organic carbon (DOC) flux to heterotrophic bacteria (Larsson \& Hagström 1979; Wolter 1982; Møller Jensen 1983). Recently, however, Bjørnsen (1989) suggested that exudation should be interpreted as a passive leakage of small metabolites across cellular membranes and should represent no more than 1$5 \%$ of phytoplankton biomass per day $(0.0005-$ $\left.0.002 \mathrm{~h}^{-1}\right)$. Other processes producing DOC therefore probably account for an additional and often dominant part of the organic matter transfer to the bacterial compartment, as e.g. direct lysis of phytoplankton cells (Jassby \& Goldman 1974; Billen 1984) or rapid diffusion from incompletely digested fecal material of macro- or micrograzers (the so-called sloppy feeding of Lampert 1978) (Jumars et al. 1989). These processes mainly pro- duce dissolved organic substances with high molecular weight which require extracellular hydrolysis before they can be taken up by bacterioplankton. For this reason, a looser coupling between bacteria and phytoplankton can be expected in situations where the latter processes of DOC-supply are dominant rather than in situations where bacteria live mainly on algal exudation products (Billen 1990).

How these ideas apply to polar systems at low temperatures is the subject of this paper. Contradictory observations have been published in previous literature concerning the role of bacteria in Arctic and Antarctic marine ecosystems. Some authors (Hodson et al. 1981; Azam et al. 1981; Hanson \& Lowery 1983; Hanson et al. 1983; Sullivan et al. 1990) reported measurements of bacterial activities in the Antarctic ocean of the same order of magnitude as those observed in temperate seas. They concluded that the microbial loop performs a similarly important role in the Antarctic marine system as in temperate and tropical systems. On the other hand, situations with high phytoplanktonic biomass and low bacterial numbers and activities have been reported in both the Arctic and Antarctic systems (Kriss et al. 1969; Sorokin 1971; Mullins \& Priddle 1987; Davidson 1985; Pomeroy et al. 1990). Pomeroy \& Deibel (1986) explained this by a dramatic decrease of bacterial activity below $2^{\circ} \mathrm{C}$, while algae continued to be active at these temperatures. This could explain the preservation of DOC, which has sometimes been found in high 
concentrations in Antarctic waters (Bolter \& Dawson 1982). This organic matter would then be exported to lower latitudes by deep oceanic circulation (Sorokin 1971).

As observations of low bacterial activity most often concern early spring situations, a possible explanation reconciling these contradictory observations may be that a time lag exists in the response of bacterioplankton to algal development. Only rather fine time-series observations could confirm this hypothesis. Such time series are difficult to obtain, however, for obvious logistic reasons. In this paper we present such data on phytoplankton and bacterioplankton development obtained during the period of ice retreat in two sectors of the Antarctic Ocean. We discuss them in the light of a simplified ecophysiological model of bacterioplankton development.

\section{Biotopes and methods}

The two data sets used in this paper result from the participation of Belgian teams, in an Australian cruise to Prydz Bay area (Marine Science Voyage 7 of the Australian Antarctic Division on board of the M/V NELLA DAN) and in the European EPOS cruise to the Weddell Sea, on board the R/V POLARSTERn Fig. 1). The Prydz Bay area was first visited in mid-January 1987 by Joiris et al. (1987) on board the R/V MARION DUFRESNE during the French Indigo III cruise. At that time, the position of the ice edge was about $65^{\circ} \mathrm{S}$. From midFebruary to end-March 1987, the area between 62 and $66^{\circ} \mathrm{S}$ was free of ice. In the Weddell Sea area, several successive transects along the meridian $49^{\circ} \mathrm{W}$ were sampled from mid-November 1988 to the beginning of January 1989 . The ice edge location varied during this period from about $60^{\circ} \mathrm{S}$ to $61.5^{\circ} \mathrm{S}$.

Chlorophyll $a$ determinations were carried out according to Lorenzen (1967). Conversion into carbon biomass was made by using a constant $\mathrm{C}$ / Chlorophyll $a$ ratio of 30 . This represents the median value derived from comparison of chlorophyll $a$ determination and algal carbon content calculated from microscopic cell size determination using Edler's (1979) formulas (Mathot pers. comm.).

At most stations, samples were taken at 10, 20, 40,60 , and $120 \mathrm{~m}$ depth. The results reported here are the means of the duplicate determinations performed at the depths located in the upper

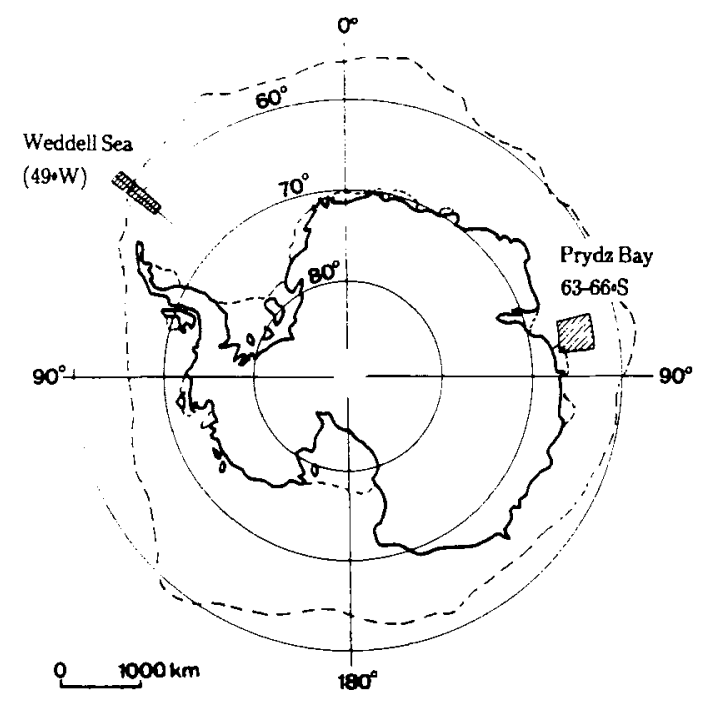

Fig. 1. The two areas in the Southern Ocean where the data sets discussed in this paper were collected.

homogeneous layer, as determined from the CTD vertical profile (range $15-50 \mathrm{~m}$ ). For only a few stations, samples were only taken at $10 \mathrm{~m}$ depth. In these cases the results reported are the means of the duplicate determinations.

Bacteria were enumerated by epifluorescence microscopy after either acridine orange (Hobbie et al. 1977) (Prydz Bay data) or DAPI staining (Porter \& Feigh 1980) (Weddell Sea data). Biovolumes were estimated on enlargements of microphotographs. Conversion into carbon biomass was done using the biovolume dependent C/biovolume ratio proposed by Simon \& Azam (1989). Differences in the bacterial biomass values reported here for the Prydz Bay area with previously reported values (Lancelot et al. 1989) originate from the use of this new conversion factor.

Bacterial production rates were measured according to the ${ }^{3} \mathrm{H}$-thymidine incorporation method of Fuhrman \& Azam (1982). ${ }^{3}$ H-thymidine was added at a final concentration of $10 \mathrm{nmol} 1^{-1}$, a concentration shown saturating for the process of incorporation. The uptake of radioactivity in the cold TCA fraction was determined after 3-4 hours incubation. Empirical calibration with cell number increase in $0.2 \mu \mathrm{m}$ filtered seawater reinoculated with $2 \mu \mathrm{m}$ filtered water (Riemann et al. 1987) was carried out several times at both sites. The conversion factors 
were $5.0 \cdot 10^{9}$ and $1.25 \cdot 10^{9}$ cells $/ \mathrm{nmol}$ thymidine incorporated in the Prydz Bay area and the Weddell Sea, respectively.

Maximum growth rate of bacteria was measured after addition of a mixture of amino acids and monosaccharides in the following final concentrations: glucose $\left(4 \mathrm{mg} \mathrm{I}^{-1}\right)$, galactose $\left(4 \mathrm{mg} \mathrm{l}^{-1}\right)$, casamino acids $\left(15 \mathrm{mgl}^{-1}\right)$, ammonium acetate $\left(1.5 \mathrm{mg} \mathrm{J}^{-1}\right)$, ammonium hydrogenophosphate $\left(2.5 \mathrm{mg} \mathrm{l}^{-1}\right)$.

Bacterial mortality was estimated according to the method developed by Servais et al. (1985, 1989). The part of grazing in overall mortality rate was estimated by comparing the mortality rate of an untreated sample with a sample filtered through a $2 \mu \mathrm{m}$ membrane and treated with a colchicine and cycloheximide (concentration 100 and $200 \mathrm{mg} \mathrm{l}^{-1}$, respectively) (Becquevort et al. unpublished data).

\section{Results and discussion}

\section{Relationship between bacterial and phytoplanktonic biomass}

When plotted against each other, no distinct relationship is apparent between bacterial and phytoplankton biomass (Fig. 2a) as would be expected in the case of a direct response of bacteria to phytoplankton. Data from successive situations in the same area, however, describe counterclockwise trajectories, indicating that phytoplankton development precedes bacterial response by about 15-30 days (Fig. 2b). This

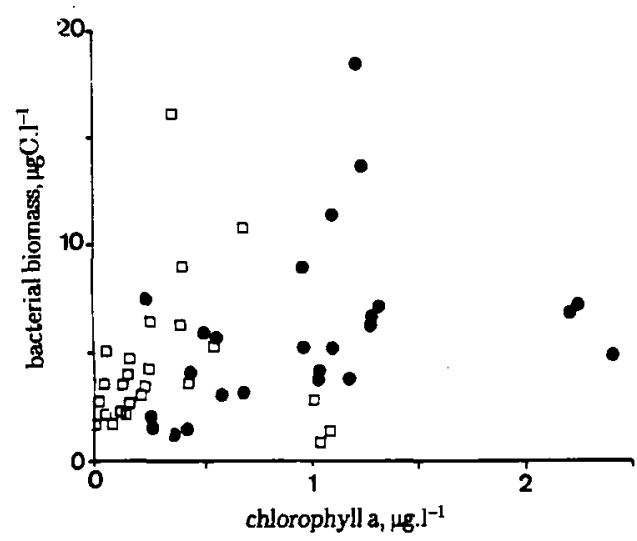

Fig. 2A. Bacterial biomass plotted against chlorophyll $a$ values in the Weddell Sea $(\odot)$ and Prydz Bay ( $\square$ ) area during the period of ice retreat.
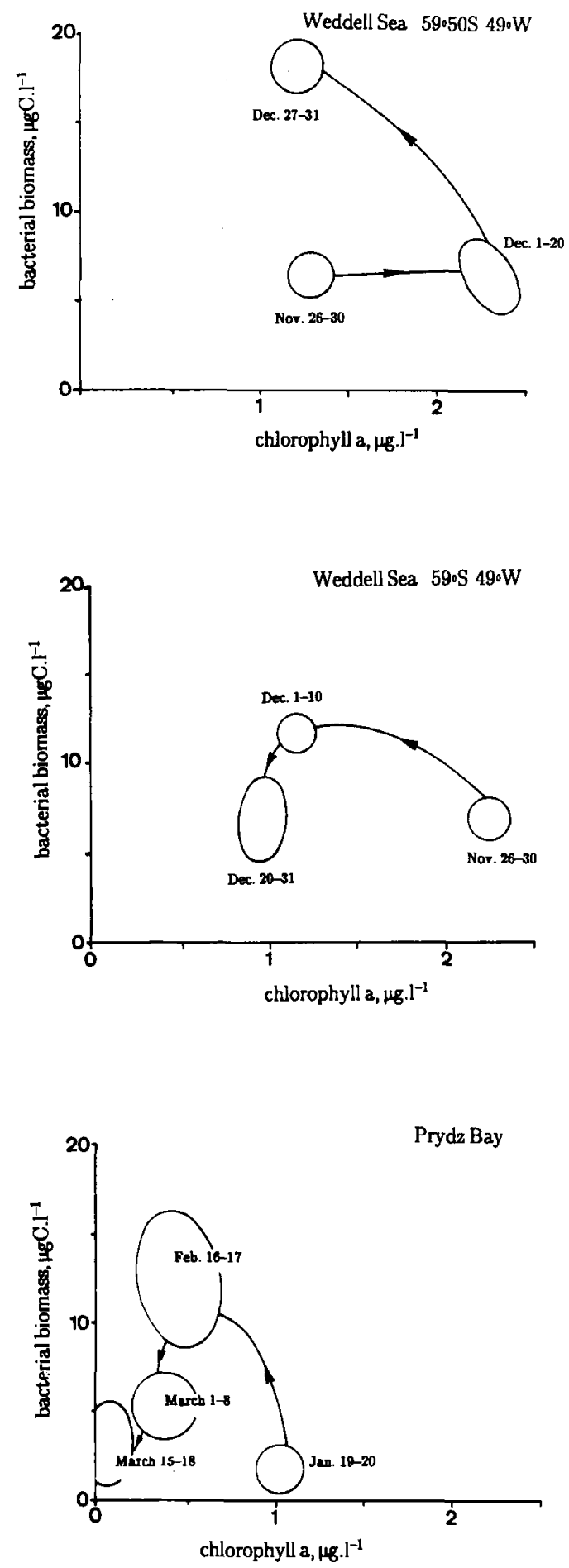

Fig. 2B. Counterclockwise trajectories of bacterial and phytoplankton biomass values at 3 sites in the Southern Occan. The counterclockwise trajectories indicate a delayed response of bacteria to algal development. 
delay in the bacterial response to phytoplankton is quite clear in the Prydz Bay data set, which shows a clear chlorophyll maximum in mid-January, while bacterial biomass peaks only about one month later (Fig. 3). In the Weddell Sea data set, a delay is also quite apparent in the response of bacteria to the algal bloom which follows the southward retreat of the ice edge (Fig. 4).

\section{Growth and mortality rates of bacterioplankton}

Specific growth rate of bacteria, as estimated by the ratio between thymidine incorporation measurements during 4 hours incubation at in situ temperature and bacterial biomass, varied between 0.05 and $0.001 \mathrm{~h}^{-1}$. An immediate increase of this growth rate was observed when amending the samples with a mixture of amino acids and monosaccharides at a final concentration of $10 \mathrm{mgCl}^{-1}$ and a $\mathrm{C}: \mathrm{N}: \mathrm{P}$ ratio of $16: 4: 1$ by weight. We considered that the value of the specific growth rate measured with this amendment represents the maximum growth rate of the natural bacterial assemblage. Use of short incubation times ( 4 hours) minimises the risk of modifications in the bacterial populations.

Fig. 5 shows the value of this maximum growth rate measured at different incubation temperature for samples from the Weddell Sea and the Prydz Bay area. Also shown are the results of similar measurements carried out in the Belgian coastal zone of the North Sea (Billen 1990). Clearly, the temperature range of the Southern

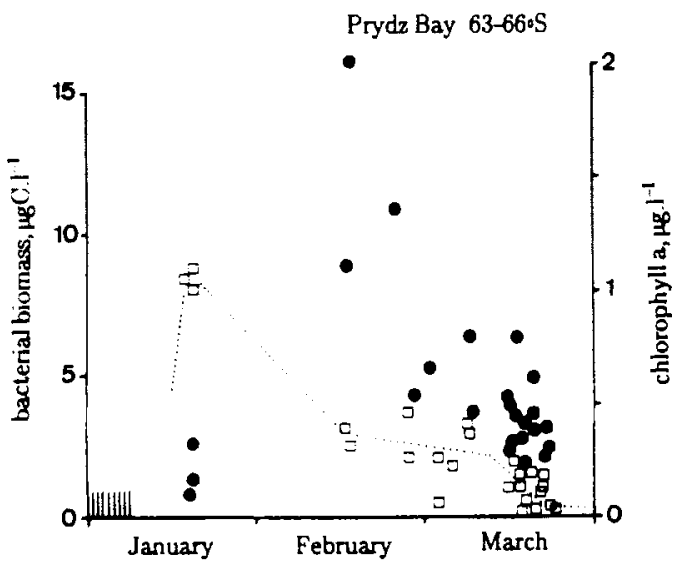

Fig. 3. Temporal variations of chlorophyll $a(\square)$ and bacterial biomass (O) during the 1987 ice-retreat period in an arca off Prydz Bay between 62 and $66^{\circ} \mathrm{S}$.
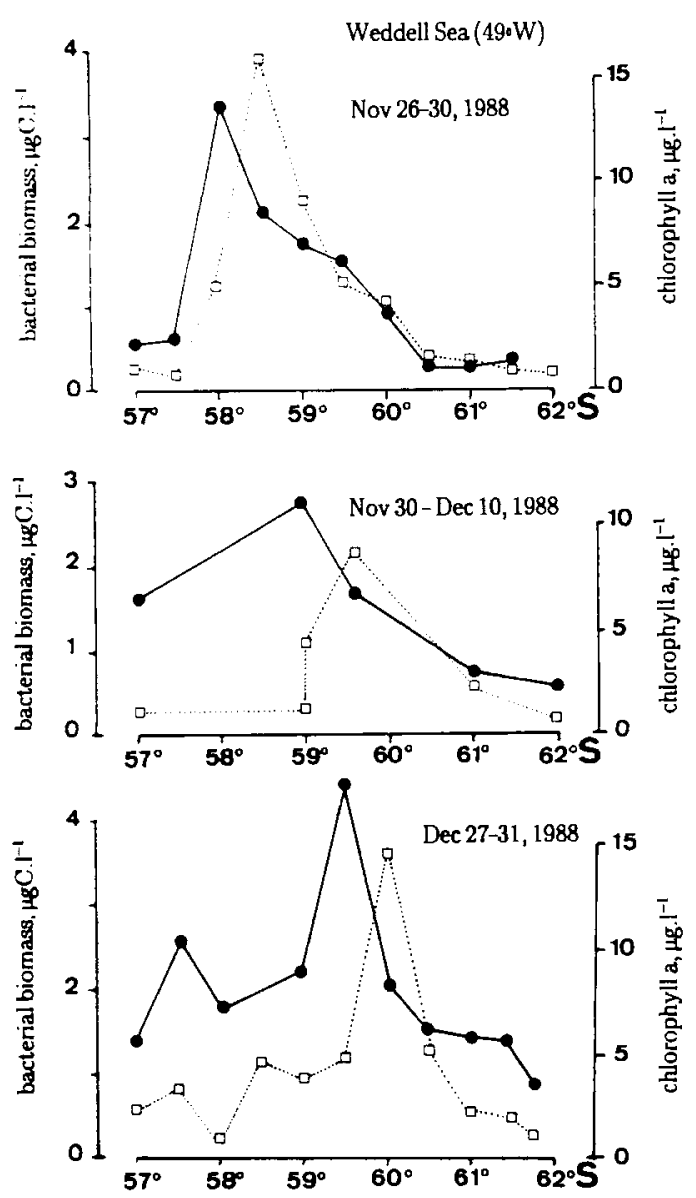

Fig. 4. N-S transects of chlorophyll $a(\square)$ and bacterial biomass (O) values observed at different times during the 1989 ice retreat period in the Weddell Sea area (meridian $49^{\circ} \mathrm{W}$ ).

Ocean $\left(-2\right.$ to $\left.+2^{\circ} \mathrm{C}\right)$ is suboptimal for bacterial growth, in contrast to what is observed for phytoplankton growth (see e.g. Lancelot et al. 1989). Nevertheless, when compared with the temperature response of bacterial communities at temperate latitudes, a remarkable adaptation to lower temperatures is found in Antarctic bacteria, with an optimum temperature $18^{\circ} \mathrm{C}$ lower with respect to the former. Antarctic bacteria at negative temperatures are able to grow as fast as North Sea bacteria in early spring conditions $\left(8-10^{\circ} \mathrm{C}\right)$.

Measured rates of bacterial mortality in the two areas studied are remarkably constant, virying between 0.002 and $0.005 \mathrm{~h}^{-1}$ in the range -2 to $+2^{\circ} \mathrm{C}$. A clear effect of temperature on mortality rate has been observed (Fig. 6). Grazing by proto- 


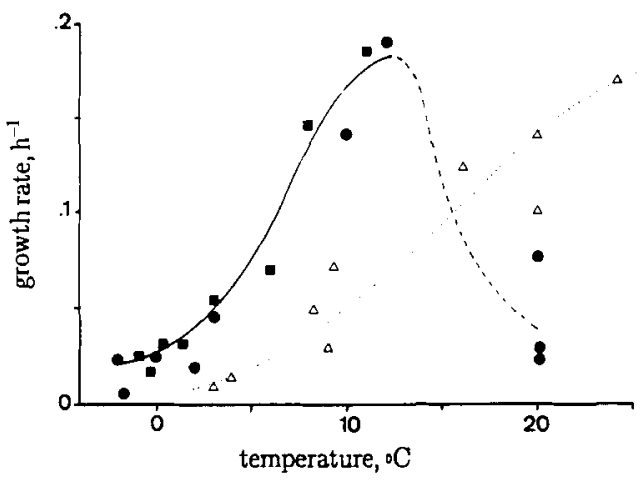

Fig. 5. Maximum specific growth rate of natural assemblages of antarctic bacteria as determined by short term thymidine incorporation measurement after amendment with direct monomeric substrates, as a function of incubation temperature. $=$ Prydz Bay; $=$ Weddell Sea. Also shown are the results of similar determinations carried out on bacterial assemblages from the Southern Bight of the North Sea $(\triangle)$.

zoans contributed to 22 to $100 \%$ of the total bacterial mortality.

\section{Modelling bacterial response to phytoplankton development}

In order to better understand the causes of the delay observed in the bacterial response to phytoplanktonic development in the Antarctic ecosystem, we used an idealised model of bacterioplankton dynamics, described and justified in details elsewhere (Servais 1986; Billen \& Fontigny 1987; Billen \& Servais 1989; Billen 1991). The basic assumption of this model is that bacterial growth rate is directly dependent on the concentration of small, monomeric substrates, while most of the DOC is under the form of macromolecules requiring extracellular hydrolysis. Uptake of direct substrates is assumed to obey an overall Michaelis-Menten kinetics (Parsons \& Strickland 1962; Wright \& Hobbie 1965). A constant fraction $\mathrm{Y}$ of the amount of substrate taken up is used for biomass production, the remaining part being respired (Servais 1986). Extracellular hydrolysis of biopolymers was also shown to obey a Michaelis-Menten kinetics (Somville \& Billen 1983; Somville 1984). Bacterial exoenzymes are mostly attached to bacterial envelopes and are present in constant amount with respect to biomass (Fontigny et al. 1987). Servais (1986) showed that it is possible to describe the bacterial utilisation of phytoplanktonic derived organic matter by assuming that it is made of two fractions $\left(\mathrm{H}_{1}, \mathrm{H}_{2}\right)$ with different susceptibilities to extracellular hydrolysis, hence different parameters of their Michaelis-Menten degradation kinetics. The process of bacterial mortality can be represented, as a first approximation, by a first order kinetics (Servais et al. 1985).

The following equations can therefore be written for describing the dynamics of bacterial growth:

$$
\begin{aligned}
& \frac{d H_{1}}{d t}=-e_{1 \max } \frac{H_{1}}{H_{1}+K_{1}} B+\mathrm{pH}_{1} \\
& \frac{d H_{2}}{d t}=-e_{2 \max } \frac{H_{2}}{H_{2}+K_{2}} B+\mathrm{pH}_{2} \\
& \frac{d S}{d t}=e_{1 \max } \frac{H_{1}}{H_{1}+K H_{1}} B \\
& +e_{2 \max } \frac{H_{2}}{H_{2}+K_{2}} B-b_{\max } \frac{S}{S+K_{s}} B+p_{e x} \\
& \frac{d B}{d t}=Y_{b_{\max }} \frac{S}{S+K_{s}} B-k_{d} B
\end{aligned}
$$

where

$e_{1 \max }, e_{2 \max }$ are the maximum rates of polymers hydrolysis per unit bacterial biomass;

$\mathrm{KH}_{1}, \mathrm{KH}_{2}$ are the half-saturation constants of polymer hydrolysis;

$\mathrm{pH}_{1}, \mathrm{pH}_{2}$ are the rate of production of polymers through phytoplankton lysis;

$b_{\max } \quad$ is the maximum rate of substrate uptake by bacteria;

$\mathrm{K}_{\mathrm{s}} \quad$ is the half-saturation constant of substrate uptake;

is the growth yield;

is the mortality constant;

is the rate of production of direct monomeric substrate through phytoplankton exudation.

The value of most of the parameters involved in these equations has been determined experimentally.

From the data shown in Fig. 5, the maximum growth rate of bacteria $\left(\mu_{\max }\right)$, and its temperature dependency can be estimated as follows:

$$
\begin{aligned}
& \mu_{\max }(\mathrm{T})=0.18 \mathrm{~h}^{-1 *}\left\{0.1+0.9^{*}\right. \\
& \left.\exp \left[-\left(\frac{\mathrm{T}-\mathrm{T}_{\mathrm{opt}}}{\mathrm{T}_{\mathrm{i}}-\mathrm{T}_{\mathrm{opt}}}\right)^{2}\right]\right\} \text { with } \begin{array}{c}
\mathrm{T}_{\mathrm{opt}}=12^{\circ} \mathrm{C} \\
\mathrm{T}_{\mathrm{i}}=5^{\circ} \mathrm{C}
\end{array}
\end{aligned}
$$




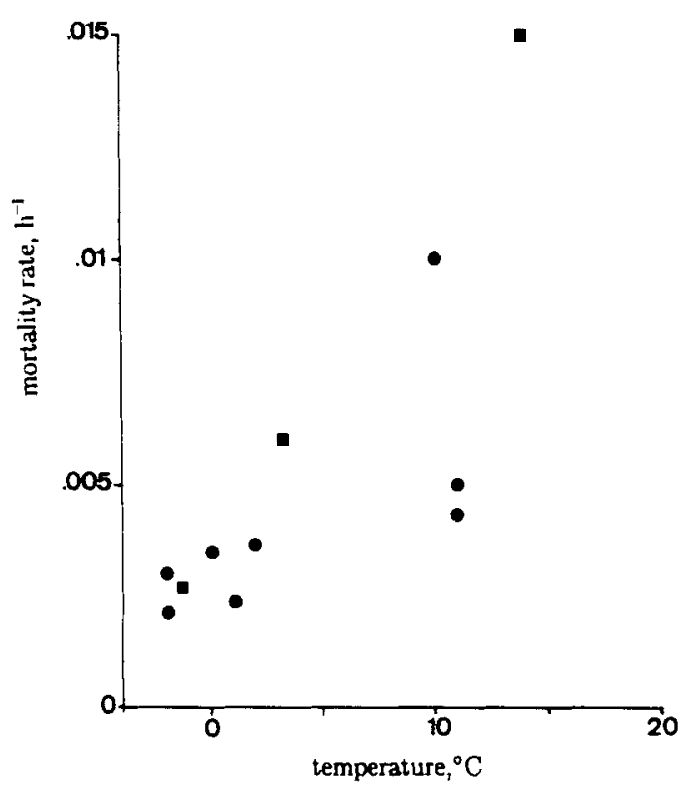

Fig. 6. Grazing rate of natural bacterial assemblages of the Weddell Sea (O) and the Prydz Bay ( $\mathbf{G}$ ) as a function of temperature.

The value of $Y$, in the absence of nutrient limitation, is generally close to 0.3 (Servais et al. 1987). $b_{\max }$ is calculated as $\mu_{\max } / Y . K_{s}$ is taken arbitrarily as $0.01 \mathrm{mgCl}^{-1}$, as this parameter does not significantly influence the results of the calculations.

The parameters characterising the rate of exoenzymatic hydrolysis of macromolecules from phytoplanktonic origin have been estimated as follows, on the basis of experiments in which the kinetics of bacterial degradation of a sonicated and filtered algal culture is measured after inoculation with a natural assemblage of bacteria (Servais 1986; Billen 1990):

$$
\begin{array}{ll}
\mathrm{e}_{I_{\max }}\left(\mathrm{T}_{\text {opt }}\right)=0.75 \mathrm{~h}^{-1}, & \mathrm{KH}_{1}=0.1 \mathrm{mgC} \cdot \mathrm{l}^{-1} \\
\mathrm{e}_{2 \max }\left(\mathrm{T}_{\text {opt }}\right)=0.25 \mathrm{~h}^{-1}, & \mathrm{KH}_{2}=2.5 \mathrm{mgC} \cdot \mathrm{I}^{-1}
\end{array}
$$

The same dependence to temperature $(T)$ as described above for $\mu_{\max }$ has been considered.

On the basis of experimental determinations of the total mortality rate constant $k_{d}$, the following relationship with temperature has been considered:

$$
k_{d}=0.004 h^{-1}+0.0005 h^{-1} \cdot T \text {. }
$$

On the other hand, it has been assumed that organic matter is produced by phytoplankton through two distinct processes: (i) exudation, pro- ducing low molecular weight substrates (S) at a rate proportional to its biomass $\left(\mathrm{k}_{\mathrm{ex}}\right)$; and (ii) lysis and/or sloppy feeding, producing high molecular weight biopolymers of two classes of utilisability $\left(\mathrm{H}_{1}, \mathrm{H}_{2}\right)$ in a ratio $1: 1$. In the basic simulation, $k_{e x}$ has been maintained at the lowest value suggested by Bjørnsen (1989) $\left(0.0005 \mathrm{~h}^{-1}\right)$. The rate of DOC production through lysis or sloppy feeding is the only adjustable parameter of the model. Forcing functions for the simulation are the observed variation of water temperature and phytoplankton biomass.

Figure 7 shows that the general trends of the observed bacterioplanktonic response to phytoplankton development both in Prydz Bay and in the Weddell Sea can be satisfactorily simulated with a single value of the first order rate constant of macromolecular DOC production by phytoplankton $\left(k_{\mathrm{lys}}=0.004 \mathrm{~h}^{-1}\right)$. In particular the model predicts a lag of about 10 to 30 days between the peaks of algal and bacterial biomass, as observed.

The rates of bacterial production calculated by the model are compared in Fig. 8 with the measured values. Agreement is generally within a factor of 2, and again, the major trends of geographical and seasonal variations are correctly simulated. As the measurements of bacterial biomass and production rates are quite independent of each other, this overall agreement constitutes a further validation of the model.

In order to obtain further insight into the factor responsible for the time lag between phytoplankton and bacterioplankton, the effect of varying some parameters or forcing variables in the model were tested. Fig. 9 shows the effect of increasing the temperature to a constant value of $5^{\circ} \mathrm{C}$ : the timing of the bacterial development is hardly modified. On the other hand, if the rate $\mathrm{k}_{\mathrm{ex}}$ of algal exudation of low molecular weight DOC is increased (at the expense of the production rate of macromolecular material, $\mathrm{k}_{\text {lys }}$ ), the model predicts a much more rapid bacterial response.

\section{Conclusion}

Our observations in the Prydz Bay and Weddell Sea areas have shown clearly that a significant time lag exists in the response of bacterioplankton to the early spring phytoplankton development. Application of our model of bacterioplankton 

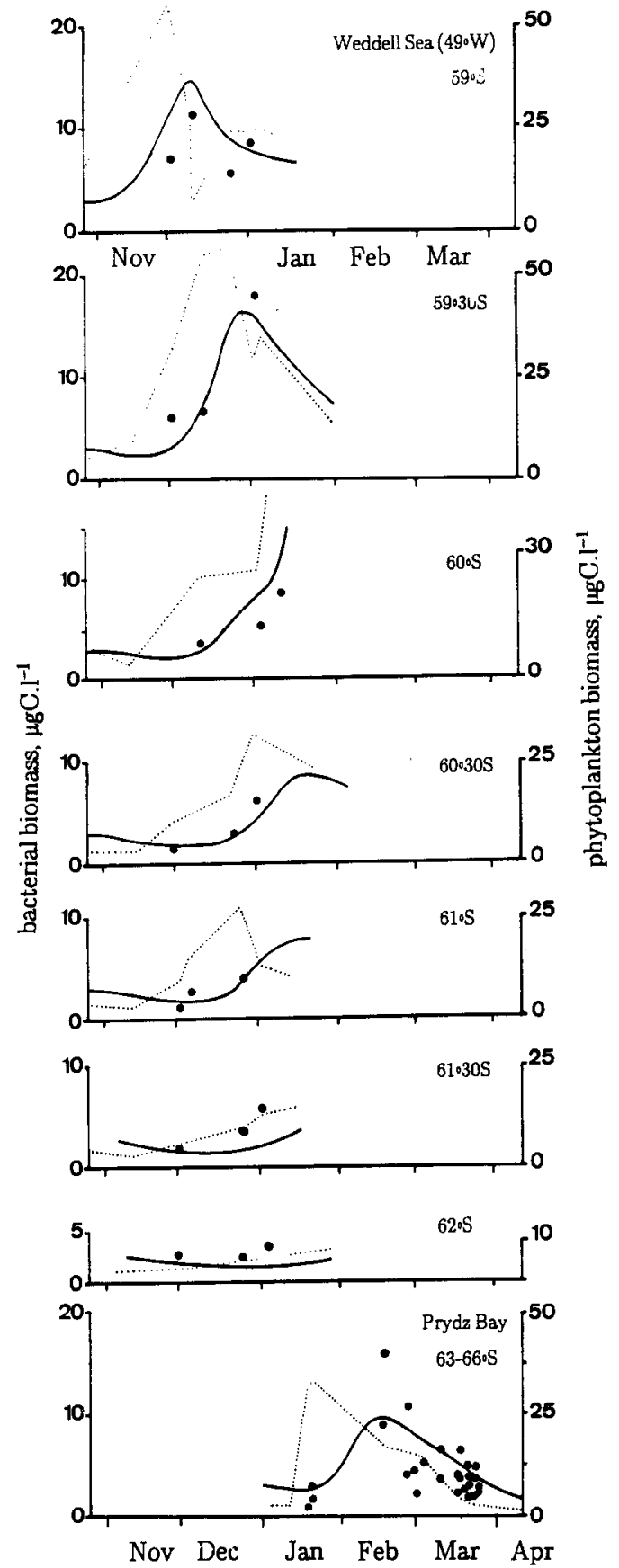

Fig. 7. Simulation of the seasonal variations of bacterial biomass in response to observed phytoplankton development (dotted curve) at different latitudes, according to the HSB model, for a single value of the rate of phytoplankton macromolecular DOC release $\left(k_{\text {lys }}=0.004 \mathrm{~h}^{-1}\right)$ and a rate of phytoplankton exudation of $0.0005 \mathrm{~h}^{-1}$. The black dots represent the observed values of bacterial biomass.
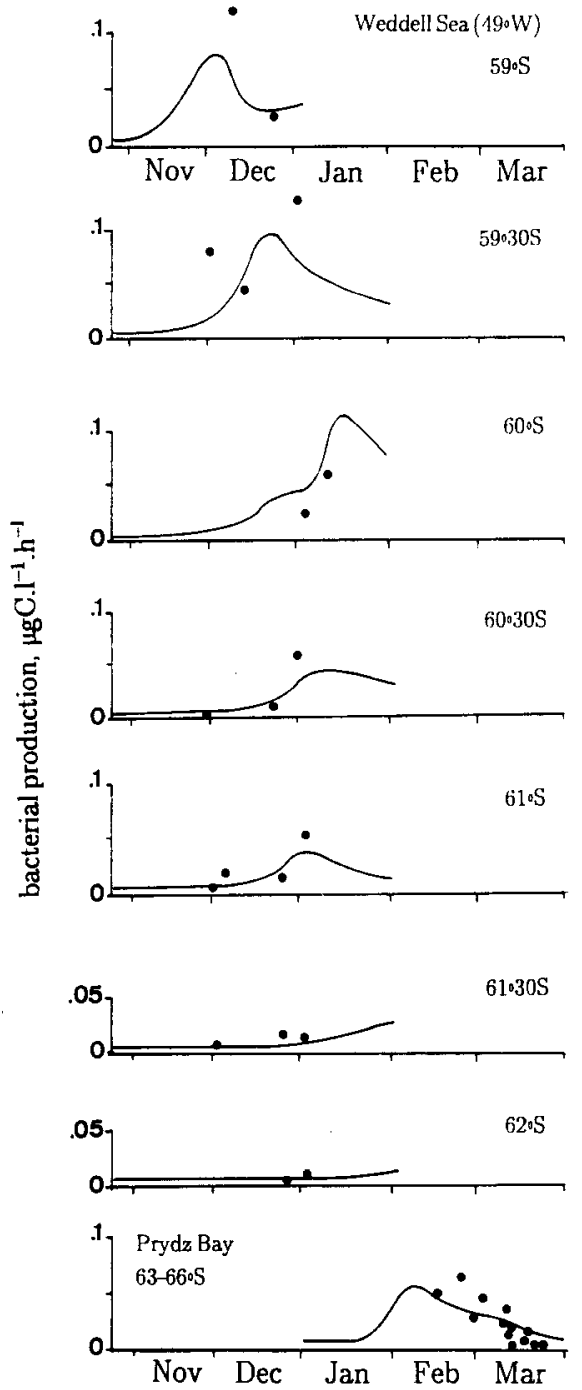

Fig. 8. Simulation of the seasonal variations of bacterial production rate in response to observed phytoplankton development (dotted curve) at different latitudes, according to the HSB model, for the same values of the parameters as in Fig. 7. The black dots represent the observed values of bacterial production rates.

dynamics, with measured values of the kinetic parameters involved, suggests that this time lag is not the result of a reduction of bacterial activity due to low temperatures. The fact that DOC produced by phytoplankton is mostly under the form of macromolecular material requiring extracellular hydrolysis before being taken up by bacterioplankton is a more likely explanation. 


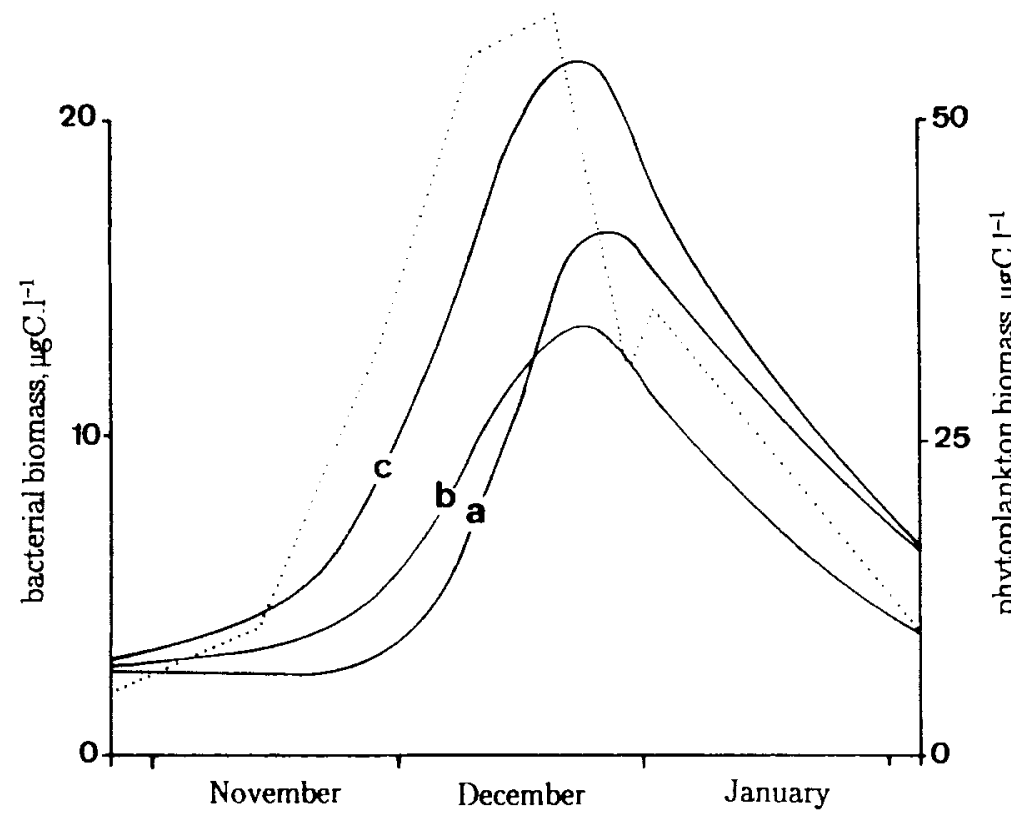

Fig. 9. Simulation of the effect of temperature $b$ ) and nature of the organic matter relcased by phytoplankton c) on the dynamics of bacterioplankton development in the Weddell Sea a) basic simulation, as in Fig. 7. $\mathrm{k}_{\mathrm{lvs}}=0.004 \mathrm{~h}^{-1}$; $k_{\text {ex }}=0.0005 \mathrm{~h}^{-1}$ observed in situ temperature.

b) simulation of the effect of increasing the temperature up to $5^{\circ} \mathrm{C}$. c) simulation of incrcased proportion of algal exudation in DOC release: $k_{\mathrm{hus}}=0.0005 \mathrm{~h}^{-1} ; \mathrm{k}_{\mathrm{cx}}=$ $0.004 \mathrm{~h}^{-1}$ observed in situ temperature.
The occurrence of a delay between phytoplankton and bacterioplankton development does not, therefore, appear to be a specific feature of polar systems. Accordingly, a similar, though shorter delay in bacterioplankton response to the spring phytoplankton bloom has been also described in temperate marine ecosystems (Billen 1990; Billen et al. 1990).

Acknowledgements. - This work is part of the Belgian Scientific Research Programme on Antarctica, funded by the Science Policy Office (Brussels. Belgium), under contract nr ANTAR/ 05. The authors are indebted to the Australian Antarctic Division for invitation to take part in Marine Science Voyage 7 to Prydz Bay (1987). Data from the Weddell Sea were collected during the European Polarstern Study (EPOS) sponsored by the European Science Foundation and the Alfred Wegener Institute for Polat and Marine Research

\section{References}

Azam. F., Ammerman. J. W. \& Cooper. N. 1981: Bacterioplankton distributional patterns and metabolic activities in the Scotia Sea. Ant. J. U.S. 16. 164-165.

Billen, G. 1984: Heterotrophic utilization and regeneration of nitrogen. Pp. 313-355 in Hobbie. J. E. \& Williams. P. J. le B. (eds.): Heterotrophic Activity in the Sea. Plenum Press.

Billen, G. 1990: Delayed development of bacterioplankton with respect to phytoplankton: a clue for understanding their trophic relationships. Arch. Hydrobiol. Beih. Ergebn, Limnol. 114, 415-429.
Billen. G. 1991: Protein degradation in aquatic environments. Chap. 7. pp. 122-142 in Chrost. R. (ed.): Enzymes in Aquatic Environments. Springer Verlag.

Billen. G. \& Fontigny. A. 1987: Dynamics of Phaeocystisdominated spring bloom in Belgian coastal waters. II. Bacterioplankton dynamics. Mar. Ecol. Prog. Ser. 37, 249-257.

Billen. G. \& Servais. P. 1989: Modélisation des processus de dégradation de la matière organique en milieu aquatique, $\mathrm{Pp}$. 219-245 in Bianchi. M. et al. (eds.): Micro-organismes dans les ecosystemes oceaniques. Masson. Paris.

Billen, G., Joiris, Cl. Meyer-Reil, L. \& Lindebloom, M. 1990: Role of bacteria in the North Sea ecosystem. Neth. J. Sea Res. 26, 265-293.

Bird. D. E. \& Kalff. J. 1984: Empirical relationship between bacterial abundance and chlorophyll concentration in fresh and marine waters. Can. J. Fish Aq. Sci. 4l, 15-1023.

Bjørnsen. P. K. 1989: Phytoplankton exudation of organic matter: Why do healthy cells do it? Limnol. Oceanogr 33. 151-154

Bolter, M. \& Dawson, R. 1982: Heterotrophic utilization of biochemical compounds in Antarctic waters. Neth. J. Sea Res 16. 315-332.

Cole. J. C.. Findlay, S. \& Pace, M. L. 1988: Bacterial production in fresh and saltwater ecosystems: a cross-system overview. Mar. Ecol. Prog. Ser. 43, 1-10.

Davidson. A. T. 1985: Aspects of the biology of Phaeocystis pouchetii. Thesis. University of Tasmania. Hobart, Australia. $231 \mathrm{pp}$.

Edler, L. 1979: Recommendations for marine biological studies in the Baltic Sea. Phytoplankton and Chlorophyll. Baltic Marine Biologists 5, 1-38.

Fontigny, A., Billen, G. \& Vives Rego, J. 1987: Some kinetics characteristics of exoprotcolytic activity in coastal sea water. Coast Est. Mar. Sci. 25, 127-134. 
Fuhrman, J. A. \& Azam, F. 1982: Thymidine incorporation area measure of heterotrophic bacterioplankton evaluation in marine surface waters: cvaluation and field result. Mar. Biol. 66, 109-120.

Hanson, R. B. \& Lowry, H. K. 1983: Nucleic acid synthesis in oceanic microplankton for the Drake Passage, Antarctica. Evaluation of steady-state growth. Mar. Biol. 73. 79-89.

Hanson, R. B., Shafer, D., Ryan, T. Pope, D. H. \& Lowry, H. K. 1983: Bacterioplankton in Antarctic Ocean waters during late austral winter: abundance, frequency of dividing cells and estimates of production. Appl. Environ. Microbiol 45, 1622-1632.

Hobbie, J. E., Daley, R. J. \& Jasper, S. 1977: Use of Nuclepore filters for counting bacteria by fuorescence microscopy. Appl. Environ. Microbiol. 33, 1225-1228.

Hodson, R. E., Azam, F., Carlucci, A. F., Fuhrman, J. A., Karl, D. M. \& Holm-Hansen, O. 1981: Microbial uptake of disolved organic matter in McMurdo Sound, Antarctica. Mar. Biol. 6I, 89-94.

Jassby, A. D. \& Goldman, C. R. 1974: Loss rates from a lake phytoplankton community. Limnol. Oceanogr. 19, 618-627.

Joiris, C., Overloop, W., Frankignoulle, M. \& Bouquegneau, J. M. 1987: Preliminary discussion of the results obtained in Antarctica during the austral summer'1986-1987: plankton ecology and ecotoxicology. In Proceedings of the Belgian Colloquium on Antarctic Research. Brussels, Oct. 20, 1987. Prime Minister's Services, Science Policy Office.

Jumars, P. A., Penry, D. L., Baross, J. A., Perry, M. J. \& Frost, B. W. 1989: Closing the microbial loop: dissolved carbon pathway to heterotrophic bacteria from incomplete ingestion, digestion and absorption in animals. Deep-Sea Res. 36, 483-495.

Kriss, A. E., Mishustina, I. E., Lebedeva, M. N. 1969: Bacterial population densities (heterotrophus) in the water column of the Southern and Indian Oceans. Mikrobiologyia 38. 511517.

Lampert, W. 1978: Release of dissolved organic carbon by grazing zooplankton. Limnol. Oceanogr. 3, 831-834.

Lancelot, C., Billen, G. \& Mathot, S. 1989: Ecophysiology of phyto- and bacterioplankton growth in the Southern Ocean, pp. 1-93 in Caschetto, S. (ed.): Belgian Scientific Research Programme on Antarctica. Scientific Results of Phase 1 (Oct 85-Jan 89). Vol. 1. Science Policy Office, Brussels, Belgium.

Larsson, U. \& Hagström, A. 1979: Phytoplankton exudate release as an energy source for the growth of pelagic bacteria. Mar. Biol. 52, 199-206.

Linley, E. A. S. Newell, R. C. \& Lucas, M. I. 1983: Quantitative relationship between phytoplankton, bacteria and heterotrophic microflagellates in shelf waters. Mar. Ecol. Prog. Ser. 12, 77-89.

Lorenzen, C. J. 1967: Determination of chlorophyll and phaeoigments: spectro-photometric equations. Limnol. Oceanogr. 12, 343-346.

Møller Jensen, L. 1983: Phytoplankton release of extracellular organic carbon molecular weight composition and bacterial assimilation. Mar. Ecol. Prog. Ser. 11, 39-48.

Mullins, B. W. \& Priddle, J. 1987: Relationships between bacteria and phytoplankton in the Bransfield Strait and Southern Drake Passage. Br. Ant. Surv. Bull. 76, 51-64.

Parsons, T. R. \& Strickland, J. D. H. 1962: On the production of particulate organic carbon by heterotrophic processes in seawater. Deep-Sea Res. 8, 211-222.

Pomeroy, L. R. \& Deibel, D. 1986: Temperature regulation of bacterial activity during the spring bloom in Newfoundland coastal waters. Science 233, 359-361.

Porter, K. G. \& Feigh, Y. S. 1980: Use of DAPI for identifying and counting aquatic microflora. Limnol. Oceanogr. 25, 943948.

Pomeroy, L. R., Macko, S. A., Ostrom, P. H. \& Dunphy, J. 1990: The microbial food web in Arctic seawater: concentration of dissolved free amino acids and bacterial abundance and activity in the Arctic Ocean and in Resolute Passage. Mar. Ecol. Prog. Ser. 61, 31-40.

Riemann, B., Bjørnsen, P. K., Newell, S. Y. \& Fallon, R. D. 1987: Calculation of bacterioplankton production from measurements of ${ }^{3} \mathrm{H}$-Thymidine incorporation. Limnol. Oceanogr. 32, 471-476.

Servais. P. 1986: Etude de la dégradation de la matière organique par les bactéries hétérotrophes en rivière. Développement d'une démarche méthodologique et application á la Meuse belge. Université Libre de Bruxelles. Faculté des Sciences. Thèse. $271 \mathrm{pp}$.

Servais, P., Billen, G. \& Vives-Rego, J. 1985: Rate of bacterial mortality in aquatic environments. Appl. Environ. Microbiol. 49. 1448-1455.

Servais, P., Billen, G. \& Hascoet, M. C. 1987: Determination of the biodegradable fraction of dissolved organic matters in waters. Water Res. 2I, 445-450.

Servais, P., Billen, G., Martinez, J. \& Vives-Rego, J. 1989: Estimating bacterial mortality by the dissapearance of $3 \mathrm{H}$ labelled intracellular DNA. Technical validation and field measurements. FEMS Microbiol. Ecology 62, 119-126.

Simon, M. \& Azam, F. 1989: Protein content and protein synthesis rates of planktonic marine bacteria. Mar. Ecol. Prog. Ser. 51, 201-213.

Somville, M. 1984: Measurement and study of substrate specificity of exoglucosidase activity in eutrophic water. Appl. Environ. Microbiol. 48, 1181-1185.

Somville, M. \& Billen, G. 1983: A method for determining exoproteolytic activity in natural waters. Limnol. Oceanogr. $28,190-193$.

Sorokin, Y. I. 1971: On the rôle of bacteria in the productivity of tropical oceanic waters. Int. Rev. Ges. Hydrobiol. 56, 148.

Sullivan, C. W., Cota, G. F., Krempin. D. W. \& Smith. W. O.. Jr. 1990: Distribution and activity of bacterioplankton in the marginal ice zone of the Weddell-Scotia Sea during austral spring. Mar. Ecol. Prog. Ser. 63, 239-252.

Wolter, K. 1982: Bacterial incorporation of organic substances released by natural phytoplankton populations. Mar. Ecol. Prog. Ser. 7, 287-295.

Wright, R. T. \& Hobbie, J. E. 1965: The uptake of organic solutes in lake water. Limnol. Oceanogr. 10, 22-28. 
